\title{
Biological Activities of Some Nepalese Medicinal Plants Used in Treating Bacterial Infections in Human Beings
}

\author{
Shandesh Bhattarai ${ }^{1}$, Ram P Chaudhary ${ }^{2}$, Robin SL Taylor ${ }^{3}$ and Suresh K Ghimire ${ }^{2}$ \\ ${ }^{1}$ Nepal Academy of Science and Technology, Khumaltar, Lalitpur, Nepal \\ ${ }^{2}$ Central Department of Botany, Tribhuvan University, Kirtipur, Kathmandu, Nepal \\ ${ }^{3}$ Community Medicine, Queens University, Kingston, Ontario, Canada
}

\begin{abstract}
In continuation of Nepalese medicinal plant screening research, we have examined the antibacterial property of 40 methanol crude extracts in vitro using disc diffusion method against Escherichia coli, Pseudomonas aeruginosa, Staphylococcus aureus and Bacillus subtilis. Overall, $95 \%$ of the extracts showed antibacterial activity against at least one Gram-negative bacteria and $90 \%$ of the extracts against at least one Gram-positive bacteria examined. Twenty-one extracts including Artemisia caruifolia, Dicranostigma lactucoides, Rauvolfia serpentina, and other plants showed antibacterial activity with all the tested bacterial species. The laboratory results are promising because several plants showed broad-spectrum antibacterial property. It is hoped that this scientific research will aware the related partners in Nepal to search for safe, efficacious, cheap alternative antibacterials of plant origin and may create an opportunity for biological conservation of the medicinal plants and cultural diversity conservation.
\end{abstract}

Key words: antibacterial activity, in vitro, ethnomedicinal plants

\section{Introduction}

Approximately 85,000 plant species world-wide are reported as being medicinally useful (Liu \& Wang 2008). Medicinal plants are a highly valued resource - the natural plant product and organic sector is considered as the fastest growing in the entire agribusiness industry (Makunga et al. 2008). Historically, the development of novel drugs was primarily through the extraction of biologically active compounds from plants which were identified through medicinal use or a variety of bioactivity screening programs (Hunter 2001). Therefore this research aims to examine the in vitro antibacterial activity of some selected ethnomedicinal plants from the Nepal Himalaya and Tarai in order to identify potential antibacterials.

Many studies have investigated traditional uses of medicinal plants, but only a few studies have followed these ethnobotanical investigations with laboratory work to verify the actual antimicrobial property of these plants (Bhattarai et al.2008a, 2008b, Shakya et al. 2008, Vaidya et al. 2006, Pokhrel et al. 2003; Page et al. 2003; Sharma et al. 2002; Prajuli et al. 2001, Taylor \& Towers 1998, Taylor et al. 2002, 1995, 1996a, 1996b, 1996c, 1996d). The scientific investigation of traditional knowledge of medicinal plants may eventually reveal new medicines, which in turn could be sold and possibly exported. In this way, plant screening research has the potential to provide economic benefit nationwide along with biodiversity conservation.

In the present study, 40 extracts from 38 ethnomedicinal plants used to treat at least one ailment that may be caused by pathogenic bacteria were collected from Manang, Mustang and Nawalparasi districts of Nepal. Plants for antibacterial screening were chosen after consultation with traditional healers and knowledgeable villagers. To screen for biological activity, methanol extracts were prepared and tested against four different bacterial species. The aim of screening was to correlate any antibacterial activity with the indigenous uses/knowledge. This can be seen as the first step in the search for primary health care 
products that are socially acceptable and scientifically valuable.

\section{Materials and Methods}

\section{Collection of samples with voucher specimens for antibacterial testing}

This research project was approved by the Central Department of Botany Research Committee of Tribhuvan University, Kirtipur, Kathmandu, Nepal and University Grant Commission, Nepal. The samples for antibacterial testing were collected during 2004 to 2007. Several field visits to the study area (Manang, Mustang and Nawalparasi districts) was conducted for the collection of samples for antibacterial testing. Samples were collected and selected because of their use among the local people. Only species that were consistently used to treat the same illness by several healers, villagers and traders were selected.

The herbarium specimens were identified with the help of standard literatures (Malla et al. 1986, Polunin \& Stainton 1984, Stainton 1988, Grierson \& Long 19832000 ) and nomenclature of the species by Hara et al. $(1978,1982)$; Hara \& Williams (1979) and Press et al. (2000). The herbarium of the specimens was prepared following the standard technique (Martin 1995). Voucher herbarium specimens were made and their numbers are listed in Table 1. These vouchers will be deposited at the Tribhuvan University Central Herbarium (TUCH), Nepal, after the first author completes his doctoral research.

Information regarding the ethnomedicinal uses of the plants was gathered by interviewing knowledgeable villagers and local healers (Bhattarai et al. 2006). For comparison, literature was searched for previously recorded uses of the same plants.

\section{Extract and disc preparation}

Plant materials were air dried and ground in an electric grinder. A $2 \mathrm{~g}$ sample of each ground plant material was soaked in $25 \mathrm{ml}$ methanol (MeOH) for a minimum of $24 \mathrm{~h}$. The sample was then suction-filtered through Whatman number 1 filter paper and the residue was again soaked with another $25 \mathrm{ml} \mathrm{MeoH}$ for another $24 \mathrm{~h}$. This process was repeated until the extracts became colourless. The filtrates were then dried with the help of an electric table fan. After being taken to complete dryness, the extract was resuspended in $2 \mathrm{ml}$ of $\mathrm{MeOH}$. This gave an extract concentration equivalent to approximately $1 \mathrm{~g}$ of dried plant material per $\mathrm{ml}$, which varied slightly depending on the plant material. Paper disks of $6 \mathrm{~mm}$ were impregnated with that extracts and allowed to dry at room temperature. Positive control disks were prepared by using the following antibiotics: ciprofloxacin, erythromycine, tetracycline (paper disks dipped in 0.25 $\mathrm{mg} / \mathrm{ml}$ ciprofloxacin, erythromycine, tetracycline, solution with $\mathrm{MeOH}$ ) and negative control disks with $\mathrm{MeOH}$ (paper disks dipped in $\mathrm{MeOH}$ ).

\section{Microorganisms used}

Four different strains of bacteria were used in the screening process: Gram-positive Staphylococcus aureus and Bacillus subtilis, and Gram-negative Escherichia coli and Pseudomonas aeruginosa. These bacteria were supplied by the Department of Clinical Microbiology, Teaching Hospital, Maharajgunj, Kathmandu and the Central Department of Microbiology, Tribhuvan University, Kirtipur, Kathmandu. Inoculum of each bacterial strain was suspended in $5 \mathrm{ml}$ of nutrient broth and incubated overnight at $37^{\circ} \mathrm{C}$. The overnight cultures were diluted $1 / 10$ with nutrient broth before use.

\section{Antibacterial assay}

The bioassay used was the standard disc diffusion assay, adapted from Taylor et al. $(1995,2002)$ to take into consideration the equipment available on site in Nepal. Standard sterile filter paper disks of $6 \mathrm{~mm}$ were saturated with plant extracts (known to have a saturation point of $20 \mu \mathrm{l}$ ). Overnight cultures were prepared by suspending 3-4 isolated colonies in $5 \mathrm{ml}$ of nutrient broth and incubating overnight at $37^{\circ} \mathrm{C}$. This overnight culture was used to inoculate the nutrient agar test plates. The test plates were inoculated with the appropriate bacterial overnight culture on a sterile cotton swab. Once inoculated, test disks and controls were added. Plates were incubated upside down for $18-24 \mathrm{~h}$ at $37^{\circ} \mathrm{C}$. Results were recorded as presence or absence of zone of inhibition, and testing was repeated three times to confirm and ensure the reliability of results.

\section{Results and Discussion}

A total of 40 extracts (2 extracts each from Ephedra gerardiana and Crateva unilocularis), were examined for antibacterial property against $S$. aureus, B. subtilis, $E$. coli and $P$. aeruginosa. Among 40 extracts examined, 
$30(75 \%)$ extracts showed antibacterial property with $S$. aureus, 31 (78 \%) extracts with $B$. subtilis, 32 (80\%) extracts with $E$. coli, and 33 (83\%) extracts with $P$. aeruginosa (Table 1).

In this study, a total of 21 species including Artemisia caruifolia, Dicranostigma lactucoides, Hyoscyamus niger, Rauvolfia serpentina, and other plants showed the broad spectrum of activity (showed antibacterial property with all the tested bacterial species), which verified the antibacterial property of the plant parts used in this study. This study is the preliminary evaluation of antibacterial activity of the plants which demonstrated that several plants have the potential to generate novel metabolites. It is expected that the plants demonstrating broad spectra of activity, may help to discover new chemical antibacterial antibiotics that could serve as selective agents for the maintenance of human health (Srinivasan et al. 2001).

Although the nature and number of active antibacterial principles involved in each extract are not clear, but the broad spectra of activity of several plant extracts are promising. Several species showed promising antibacterial property which demonstrates their importance in traditional remedies in remote populations of the study areas where western medicines are not readily available. Antibacterial activity of 40 extracts against two Gram-positive and two Gramnegative bacteria along with their traditional uses were given below in Table 1 .

Table 1: Antibacterial activity of some Nepalese medicinal plants against two Gram-positive and two Gram-negative bacteria

\begin{tabular}{|c|c|c|c|c|c|c|c|}
\hline SN & $\begin{array}{l}\text { Scientific name (Family), } \\
\text { Voucher number }\end{array}$ & $\begin{array}{l}\text { Part } \\
\text { used }\end{array}$ & Traditional uses & S.a. & B.s. & P.a. & E.c. \\
\hline 1 & $\begin{array}{l}\text { Achyranthes aspera L. } \\
\text { (Amaranthaceae), V } 2401 .\end{array}$ & $\mathrm{Rt}$ & $\begin{array}{l}\text { Diarrhoea, dysentery, stomachache, fever, } \\
\text { skin diseases, cholera, boils, astringent, } \\
\text { food poisoning, diuretic, hemorrhoids, } \\
\text { emetic, hysteria, toothache, stomach } \\
\text { troubles, (Muller-Boker 1999, Manandhar } \\
\text { 2002; Bhattarai 2007). }\end{array}$ & - & + & + & + \\
\hline 2 & $\begin{array}{l}\text { Aconitum spicatum (Bruhl) } \\
\text { Stapf (Ranunculaceae), V } 3457 .\end{array}$ & $\mathrm{Rt}$ & $\begin{array}{l}\text { Infected wounds, boils, fever, cuts, to } \\
\text { counteract the effects of poison, allergy, } \\
\text { edema (Rajbhandari et al. } 1995 \text {, Manandhar } \\
\text { 2002). }\end{array}$ & - & - & - & - \\
\hline 3 & $\begin{array}{l}\text { Arnebia benthamii (Wall. ex G. } \\
\text { Don) I.M. Johnst. (Boraginaceae), } \\
\text { V } 3102 .\end{array}$ & Wp & $\begin{array}{l}\text { Chronic fever, blood fever, lung disease, } \\
\text { swelling (Bista \& Bista 2005). }\end{array}$ & + & + & + & + \\
\hline 4 & $\begin{array}{l}\text { Artemisia caruifolia } \text { Buch.-Ham. } \\
\text { (Asteraceae), V } 4003 .\end{array}$ & $\mathrm{Wp}$ & $\begin{array}{l}\text { Cough, asthma, cold, fever, allergies of the } \\
\text { skin (Manandhar 2002). }\end{array}$ & + & + & + & + \\
\hline 5 & $\begin{array}{l}\text { Artemesia gmelinii Weber ex } \\
\text { Stechm. (Asteraceae), V } 4004 .\end{array}$ & $\mathrm{Wp}$ & $\begin{array}{l}\text { Fever, cough, cold, sore throat, ear pain, } \\
\text { skin wounds, allergies (Bhattarai et al. } \\
\text { 2006). }\end{array}$ & + & - & + & + \\
\hline 6 & $\begin{array}{l}\text { Artemisia indica Willd. } \\
\text { (Asteraceae), V } 4005 .\end{array}$ & $\mathrm{Wp}$ & $\begin{array}{l}\text { Diarrhea, dysentery, conjunctivitis, } \\
\text { wounds, cuts, cough, sinusitis anthelm- } \\
\text { intic, abdominal pains, asthma, diuretic, } \\
\text { ringworm (Manandhar 2002). }\end{array}$ & + & + & & \\
\hline
\end{tabular}




\begin{tabular}{|c|c|c|c|c|c|c|c|}
\hline 7 & $\begin{array}{l}\text { Asparagus racemosus } \\
\text { Willd. (Liliaceae), V } 2406 .\end{array}$ & $\mathrm{Rt}$ & $\begin{array}{l}\text { Dysentery, diarrhoea, gonorrhaea, painful uri- } \\
\text { nation, urinary tract infection, diuretic, sto- } \\
\text { machic, epilepsy, inflammations, eye diseases, } \\
\text { throat complaints, worms, (Rajbhandari et al. } \\
\text { 1995, Muller-Boker 1999, Manandhar 2002, } \\
\text { Bhattarai 2007). }\end{array}$ & + & + & + & + \\
\hline 8 & $\begin{array}{l}\text { Azadirachta indica A. Juss. } \\
\text { (Meliaceae), V } 2481 .\end{array}$ & $\mathrm{L}$ & $\begin{array}{l}\text { Diarrhoea, stomachache, wounds, fever, } \\
\text { cough, bleeding from gums, burns, dysentery, } \\
\text { antidotal, diuretic, skin diseases, urinary com- } \\
\text { plaints, swelling, hemorrhoids (Rajbhandari } \\
\text { et al. 1995, Muller-Boker 1999, Manandhar } \\
\text { 2002, Bhattarai 2007). }\end{array}$ & + & - & + & + \\
\hline 9 & $\begin{array}{l}\text { Berberis aristata DC. } \\
\text { (Berberidaceae), V } 4567 .\end{array}$ & $\mathrm{Br}$ & $\begin{array}{l}\text { Diarrhoea, dysentery, edema, eyes diseases, } \\
\text { jaundice, skin diseases, malarial fever } \\
\text { (Rajbhandari et al. 1995, Manandhar } 2002 \text {, } \\
\text { Bhattarai et al. 2006). }\end{array}$ & + & + & + & + \\
\hline 10 & $\begin{array}{l}\text { Bistorta affinis (D. Don) Greene } \\
\text { (Polygonaceae), V } 3083 .\end{array}$ & $\mathrm{Wp}$ & $\begin{array}{l}\text { Cough, tonsillitis, fever, diarrhoea, dysentery, } \\
\text { cold (Kletter \& Krieckbaum 2001, Bhattarai } \\
\text { et al. 2006). }\end{array}$ & + & + & + & + \\
\hline 11 & $\begin{array}{l}\text { Caragana gerardiana Royle } \\
\text { (Fabaceae), V } 4006 .\end{array}$ & Fl & Fever & + & - & + & - \\
\hline 12 & $\begin{array}{l}\text { Cinnamomum camphora (L.) J. } \\
\text { Presl (Lauraceae), V } 2425 .\end{array}$ & $\mathrm{L}$ & $\begin{array}{l}\text { Cough, cold, anthelmintic, inflammations, } \\
\text { sedative effect in hysteria, (Rajbhandari et } \\
\text { al. 1995, Manandhar 2002, Bhattarai 2007). }\end{array}$ & + & + & - & + \\
\hline 13 & $\begin{array}{l}\text { Cissampelos pareira L. } \\
\text { (Menispermaceae), V } 2435 .\end{array}$ & Rt \& L & $\begin{array}{l}\text { Stomachache, diarrhoea, cough, fever, swell- } \\
\text { ing of gums, painful urination, wounds, di- } \\
\text { uretic, urinary troubles, skin diseases } \\
\text { (Rajbhandari et al. 1995, Manandhar 2002, } \\
\text { Bhattarai 2007). }\end{array}$ & + & + & + & + \\
\hline 14 & $\begin{array}{l}\text { Cissus repens Lam. (Vitaceae), V } \\
2433 .\end{array}$ & $\mathrm{L} \& \mathrm{St}$ & Cough, bronchitis (Bhattarai 2007). & + & + & + & + \\
\hline 15 & $\begin{array}{l}\text { Crateva unilocularis Buch.-Ham. } \\
\text { (Capparaceae), V } 2437 .\end{array}$ & $\mathrm{Br}$ & $\begin{array}{l}\text { Sinusitis, stomachache, cuts, wounds, } \\
\text { boils, fever, urinary complaints } \\
\text { (Manandhar 2002, Bhattarai 2007). }\end{array}$ & + & - & - & + \\
\hline 16 & $\begin{array}{l}\text { Crateva unilocularis Buch.-Ham. } \\
\text { (Capparaceae), V } 2437 .\end{array}$ & $\mathrm{L}$ & $\begin{array}{l}\text { Sinusitis, stomachache, cuts, wounds, } \\
\text { boils, fever, urinary complaints } \\
\text { (Manandhar 2002, Bhattarai 2007). }\end{array}$ & - & + & + & + \\
\hline 17 & $\begin{array}{l}\text { Cupressus torulosa D. Don } \\
\text { (Cupressaceae), V } 4017 .\end{array}$ & $\mathrm{Sd}$ & Sinusitis, gingivitis & + & + & + & + \\
\hline 18 & $\begin{array}{l}\text { Ephedra gerardiana Wall. ex Stapf } \\
\text { (Ephedraceae), V } 4008 .\end{array}$ & $\mathrm{Wp}$ & $\begin{array}{l}\text { Syphilis, bronchitis, cuts, wounds, res- } \\
\text { piratory diseases, kidney fever, cough, } \\
\text { skin diseases, asthma, hay fever } \\
\text { (Rajbhandari et al. 1995, Manandhar } \\
\text { 2002, Bista \& Bista 2005, Bhattarai et al. } \\
\text { 2006). }\end{array}$ & + & + & + & + \\
\hline
\end{tabular}


Syphilis, bronchitis, cuts, wounds, skin infections, kidney fever, hay fever, cough, respiratory diseases (Rajbhandari et al. 1995, Manandhar 2002; Bista \& Bista 2005, Bhattarai et al. 2006).

Equisetum debile Roxb. ex Vaucher Wp (Equisetaceae), V 2486.

21

Euphorbia royleana Boiss. L \& Lt (Euphorbiaceae), V 2515.

Gentiana robusta King ex Hook. f. (Gentianaceae), V 170.

Hyoscyamus niger $\mathrm{L}$.

(Solanaceae), V 2236.

Lawsonia inermis L. (Lythraceae), $\mathrm{V}$ L 2508.

Mangifera indica L. (Anacardiaceae), $\mathrm{Br}$ V 2529.

Malva verticillata L. (Malvaceae), V Rt 156.

Pogostemon benghalensis (Burm.f.) L Kuntze (Lamiaceae), V 2571.

Pterocephalus hookeri (C.B. Clarke) Wp Diels (Dipsacaceae), V. 4089.
Burns, scabies, malarial fever (Manandhar 2002, Bhattarai 2007).

Diarrhoea, dysentery, wounds inside the ear, ear pain, cuts, fever, boils, cough, stomach disorders, asthma, anthelmintic (Manandhar 2002, Bhattarai 2007).

Stomachache, fever, cuts, wounds, boils (Kletter \& Kriechbaum 2001; Bhattarai et al. 2006).

Whooping cough, gingivitis, asthma, tooth pain (Manandhar 2002, Bista \& Bista 2005, Bhattarai et al. 2006).

Wounds, burns, toothaches, skin diseases, menstrual problems and disorders (Rajbhandari et al. 1995, Bhattarai 2007).

Cough, bloody dysentery, burns, gingivitis, diarrhoea, bronchitis, urinary tract infection, diuretic, toothaches, scabies, skin diseases, asthma, anthelmintic (Rajbhandari et al. 1995, Manandhar 2002, Bhattarai 2007).

Cough, tonsillitis, diarrhoea, wound, urinary diseases, kidney diseases, kidney fever, (Bista \& Bista 2005, Bhattarai et al. 2006).

Skin diseases (ringworm, herpes) (Manandhar 2002).

Asthma, bronchitis, urinary tract infection (Bhattarai 2007).

Cough, diarrhoea, fever (Bhattarai 2007, Manandhar 2002).

Chronic diseases, fever, cough, poison fever (Kletter \& Kriechbaum 2001, Manandhar 2002, Bista \& Bista 2005).

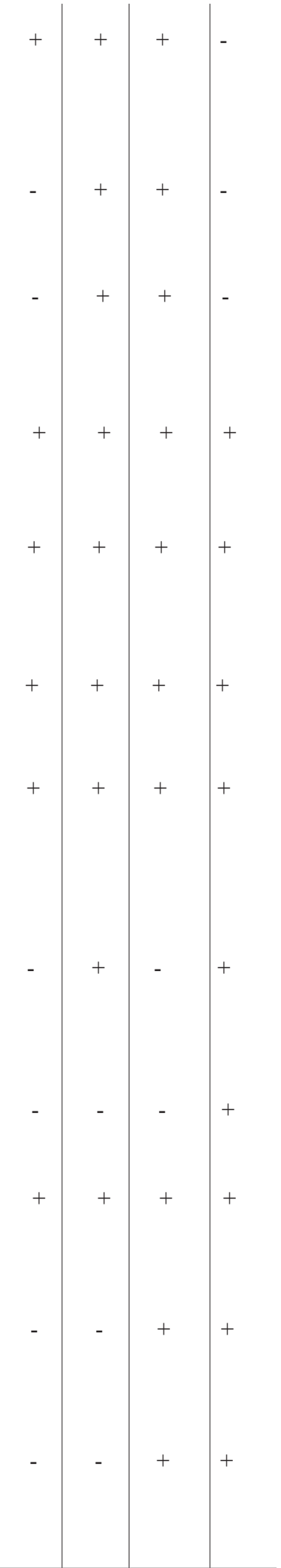




\begin{tabular}{|c|c|c|c|c|c|c|c|}
\hline 31 & $\begin{array}{l}\text { Ranunculus laetus Wall.ex D. Don } \\
\text { (Ranunculaceae), V } 4001 .\end{array}$ & $\mathrm{Wp}$ & $\begin{array}{l}\text { Cuts, wounds, stomachache, } \\
\text { sinusitis (Manandhar 2002). }\end{array}$ & + & + & + & - \\
\hline 32 & $\begin{array}{l}\text { Rheum australe D. Don } \\
\text { (Polygonaceae), V } 3085 .\end{array}$ & Rt & $\begin{array}{l}\text { Stomachic, malarial fever (Manandhar } \\
\text { 2002). }\end{array}$ & + & + & + & + \\
\hline 33 & $\begin{array}{l}\text { Rauvolfia serpentina (L.) Benth. ex } \\
\text { Kurz (Apocynaceae), V } 2592 .\end{array}$ & Rt & $\begin{array}{l}\text { Dysentery, fever, cut, wounds, boils, } \\
\text { stomachache, menstrual problems and } \\
\text { disorders (Rajbhandari et al. 1995, } \\
\text { Manandhar 2002, Bhattarai 2007). }\end{array}$ & + & + & + & + \\
\hline 34 & $\begin{array}{l}\text { Rhododendron lepidotum Wall. ex G. } \\
\text { Don (Ericaceae), V } 2122 .\end{array}$ & $\mathrm{L}, \& \mathrm{Fl}$ & $\begin{array}{l}\text { Fever, cough, cold, tonsillitis (Lama et } \\
\text { al. 2001, Manandhar 2002, Bhattarai et } \\
\text { al. 2006). }\end{array}$ & + & + & + & + \\
\hline 35 & $\begin{array}{l}\text { Selinum wallichianum (DC.) Raizada \& } \\
\text { Saxena (Apiaceae), V } 435 .\end{array}$ & $\mathrm{Rt}$ & $\begin{array}{l}\text { Stomachache, cuts, wounds, cough, cold, } \\
\text { fever (Lama et al. 2001; Manandhar } \\
\text { 2002, Devkota \& Karmacharya 2003, } \\
\text { IUCN-Nepal 2004, Bhattarai et al. } \\
\text { 2006). }\end{array}$ & + & + & + & + \\
\hline 36 & $\begin{array}{l}\text { Stellera chamaejasme L. } \\
\text { (Thymelaeaceae), V } 3072 .\end{array}$ & Rt & $\begin{array}{l}\text { Skin diseases, swelling, wounds (GoN } \\
\text { 2007, Kletter \& Krieckbaum 2001, } \\
\text { Manandhar 2002). }\end{array}$ & + & + & + & + \\
\hline 37 & $\begin{array}{l}\text { Tinospora sinensis (Lour.) Merr. } \\
\text { (Menispermaceae), V } 2711 .\end{array}$ & $\begin{array}{l}\text { Rt, St } \\
\& \mathrm{~L}\end{array}$ & $\begin{array}{l}\text { Chronic diarrhoea, chronic dysentery, } \\
\text { cough, stomachache, urinary troubles, } \\
\text { diuretic (Rajbhandari et al. 1995, } \\
\text { Manandhar 2002, Bhattarai 2007). }\end{array}$ & + & + & + & + \\
\hline 38 & Urtica dioica L. (Urticaceae), V 3553. & $\mathrm{~L} \& \mathrm{St}$ & $\begin{array}{l}\text { Cough, dental caries, cuts, wounds, } \\
\text { fever, boils, diarrhoea, } \\
\text { dysentery, asthma, anthelmintic, } \\
\text { menstrualdisorders (Rajbhandari et al. } \\
\text { 1995). }\end{array}$ & + & - & + & - \\
\hline 39 & $\begin{array}{l}\text { Woodfordia fruticosa (L.) Kurz } \\
\text { (Lythraceae), V } 2509 .\end{array}$ & $\mathrm{Fl}$ & $\begin{array}{l}\text { Fever, diarrhoea, dysentery (Manandhar } \\
\text { 2002, Bhattarai 2007). }\end{array}$ & + & + & + & + \\
\hline 40 & $\begin{array}{l}\text { Xeromphis spinosa (Thunb.) Keay } \\
\text { (Rubiaceae), V } 2613 .\end{array}$ & $\mathrm{Br}$ & Stomachache (Bhattarai 2007). & - & + & - & - \\
\hline
\end{tabular}

Key: Parts used refers to the part of the plant extracted and tested: L, leaves; Fl, flowers; Wp, whole plants; Rt, roots; St, Stems; Br, bark; Lx, latex; Sd, seeds; $\mathrm{V}$, Voucher number; +: testing resulted in a zone of inhibition, indicating the presence of antibacterial activity, -: testing resulted in no zone of inhibition, indicating the absence of antibacterial activity, Test organisms: S.a.: Staphylococcus aureus, P.a.: Pseudomonas aeruginosa, E.c.: Escherichia coli, B.s.: Bacillus subtilis.

Three extracts i.e., from Asparagus racemosus, Mangifera indica and Phyllanthus urinaria used to treat urinary tract infection showed antibacterial activity against at least one Gram-positive and Gramnegative bacteria along with Escherichia coli. Similarly, Artemisia indica which is used to treat conjunctivitis showed antibacterial activity with Staphylococcus aureus. Of 15 extracts tested against diarrhoea and dysentery, 14 showed antibacterial activity against at least one Gram-positive and one Gram-negative bacteria.

Among 23 extracts tested, against skin infections (boils, infected wounds, wounds), five extracts did not show antibacterial activity with Pseudomonas 
aeruginosa and seven extracts with Staphylococcus aureus. Among 26 extracts tested used to treat fever, 23 showed antibacterial activity with at least one Grampositive and 25 with at least one Gram-negative bacteria.

Aconitum spicatum, used by the amchis (Tibetan Doctors) with different confindential mixtures was unable to show positive activity towards any bacterial species tested (Table 1). There may be many possible reasons for the negative activity of the extracts in this study. Firstly, the tested plant extract may not contain antibacterial compounds. The plants may have other medicinal uses, such as analgesic and others. Many antimicrobial screening studies use a relatively small number of microorganisms for testing. It is possible that these plants contain antibacterial compounds against pathogenic bacteria other than those tested in this study. In addition, the lack of activity may be because of degradation of active chemicals during the drying process, the extraction process, or perhaps methanol was not an appropriate solvent to extract the active constituents of these plant species.

Comparing the result shown by Gram-positive and Gram-negative bacteria, S. aureus and B. subtilis were found to be less sensitive then Gram-negative $P$. aeruginosa and E. coli. Overall, $95 \%$ of the extracts showed antibacterial activity against at least one Gram-negative bacteria and $90 \%$ of the extracts against at least one Gram-positive bacteria examined. The activity against Gram-negative bacteria was a surprise finding. It has been expected that greater number of extracts were active against Gram-positive bacteria than Gram-negative bacteria (McCutcheon et al. 1992, Taylor et al. 1995). This has been explained by the difference in the cell wall make up of Gramnegative and positive bacteria, with Gram-negative having a more complex, and therefore possibly harder to combat the cell wall (Bhattarai et al. 2008b).

In this study, the findings of more plant species with inhibitory activity against Gram-negative bacteria may be because of selection bias towards illnesses more commonly caused by Gram-negative bacteria (such as fever and diarrhoea). The results of this research are encouraging, as most of the selected plants appeared to contain antibacterial substances. It is hoped that the Nepalese medicinal plant screening research will aware the related partners in Nepal to search for safe, efficacious, cheap alternative antibacterials of plant origin and may create an opportunity for biological conservation of the medicinal plants and cultural diversity conservation.

\section{Acknowledgement}

The first author is thankful to Volkswagen foundation/Germany, University Grants Commission, Nepal and NUFU/Norway for the financial support. We are grateful to the local people of the study areas for sharing their valuable ethnobotanical information, and the Annapurna Conservation Area Project (ACAP) for research permission. We are thankful to the Central Department of Microbiology of Tribhuvan University, Kirtipur, Kathmandu, Nepal and the Department of Clinical Microbiology, Teaching Hospital, Maharagjung, Kathmandu for kindly providing the bacterial strains.

\section{References}

Bhattarai, S., R.P. Chaudhary and R.S.L. Taylor. 2006. Ethnomedicinal plants used by the people of Manang district, Central Nepal. Journal of Ethnobiology and Ethnomedicine 2: 41.

Bhattarai, S., R.P. Chaudhary and R.S.L. Taylor. 2008a. Screening of selected ethnomedicinal plants of Manang district, Central Nepal for antibacterial activity. Ethnobotany 20: 9-15.

Bhattarai, S., R.P. Chaudhary and R.S.L. Taylor. 2008b. Antibacterial activity of selected ethnomedicinal plants of Manang district, central Nepal. Journal of Theoretical and Experimental Biology 5(1 \& 2): 1-9.

Bhattarai, S. 2007. Antibacterial activity of some selected ethnomedicinal plants of

Nawalparasi district, Central Nepal. Report submitted to the University Grants Commission, Bhaktapur, Kathmandu, Nepal.

Bista, T. and G. Bista. 2005. Himalayan doctors and healing herbs: The Amchi traditional medicinal plants of Mustang. Mera Publications for Lo-Kunphen Mentsikhang. 96 pp.

Devkota, R. and S.D. Karmacharya. 2003. Documentation of indigenous knowledge of medicinal plants in Gwallek VDC of Baitadi district, Far Western Nepal. BotanicaOrientalis 135-143.

GoN. 2007. Medicinal plants of Nepal (Revised). Bulletin of the Department of Plant Resources No. 28. Government of Nepal (GoN), Ministry of Forest and Soil Conservation, Department of Plant Resources, Thapathali, Kathmandu, Nepal.

Grierson, A.J.C. and D.G. Long. 1983-2000. Flora of Bhutan. Vol. I \& II. Part. I-III, Royal Botanic Garden, Edinburgh and Royal Government of Bhutan. 
Hara, H., W.T. Stearn and L.H.J. Williams. 1978. An enumeration of the flowering plants of Nepal. Volume I. British Museum of Natural History, London.

Hara, H. and L.H.J. Williams. 1979. An enumeration of the flowering plants of Nepal.

Volume II. British Museum of Natural History, London.

Hara, H., A.O. Charter and L.H.J. Williams. 1982. An enumeration of the flowering plants of Nepal. Volume III. British Museum of Natural History, London.

Hunter, D. 2001. Life in the fast lane: high-throughput chemistry for lead generation and optimisation. Journal of Cellular Biochemistry (Suppl.) 37: 22-27.

IUCN-Nepal. 2004. National register of medicinal and aromatic plants. IUCN Nepal Country Office for His Majesty's Government of Nepal, Ministry of forest and soil conservation. $202 \mathrm{pp}$.

Kletter, C. and M. Krieckbaum. 2001. Tibetan Medicinal Plants. MedPharm GmbH Scientific Publishers, Birkenwaldstr, Stuttgart, Germany.

Lama, Y.C., S.K. Ghimire and Y.A. Thomos. 2001. Medicinal plants of Dolpo: Amchis knowledge and conservation. WWF Nepal Program, Kathmandu, Nepal.

Liu, Y. and M.W. Wang. 2008. Botanical drugs: Challenges and opportunities-contribution to Linnaeus memorial symposium 2007. Life Sciences 82: 445-449.

Makunga, N.P., L.E. Philander and M. Smith. 2008. Current perspectives on an emerging formal natural products sector in South Africa. Journal of Ethnopharmacology 119: 365-375.

Malla, S.B., S.B. Rajbhandari, T.B. Shrestha, P.M. Adhikari, S.R. Adhikari and

P.R. Shakya. 1986. Flora of Kathmandu valley. Bulletin of Department of Medicinal Plants of Nepal, No. 11:pp

Manandhar, N.P. 2002. Plants and people of Nepal. Timber Press, Inc. Portland, Oregon, U.S.A.

Martin, G.J. 1995. Ethnobotany: A methods manual. Chapman and Halls, London.

McCutcheon, A.R., S.M. Ellis, R.E.W. Hancock and G.H.N. Towers. 1992. Antibiotic screening of medicinal plants of the British Columbian native people. Journal of Ethnopharmacology 37: 213-223.

Mueller-Boker, U. 1999. The Chitwan Tharus in southern Nepal: An ethnoecological approach. Nepal Research Centre Publication No 21. Frans Steiner Verlag, Stuttgart, Germany.

Page, D., C.B. Baniya and R.S.L. Taylor. 2003. Isolation of biologically active compounds from ethnobotanically important Nepalese lichens. Ecoprint 10(1):1-6.

Parajuli, S., R.P. Chaudhary and R.S.L. Taylor. 2001. Antibacterial activity of medicinal plants used to treat skin ailments in Kaski district, Nepal. In: Environment and Agriculture: Agriculture and Polluton in South Asia (Eds. P.K., Jha, S.R. Bharal, S.B. Karmacharya, H.D. Lekhak, P. Lacoul and C.B. Baniya). Ecological Society, Nepal. pp. 242-249.

Pokhral, N.R., R.P. Adhikari and M.P. Baral. 2003. In vitro screening and evaluation of antimicrobial activities of some medicinal plants of Nepal. Nepal Journal of Science and Technology 5:13-17.
Polunin, O. and A. Stainton. 1984. Flowers of the Himalaya. Oxford University Press, New Delhi, India. 283 pp.

Press, J.R., K.K. Shrestha and D.A. Sutton. 2000. Annotated checklist of the flowering plants of Nepal. Natural History Museum, London and Central Department of Botany, Tribhuvan University, Kathmandu. 430 pp.

Rajbhandari, T.K., N.R. Joshi, T. Shrestha, S.K.G. Joshi and B. Achraya. 1995. Medicinal plants of Nepal for Ayurvedic drugs. HMGN, Natural Products Development Division, Thapatali, Kathmandu, Nepal.

Shakya, M.N., R. Pradhan and R. Ranjitkar. 2008. A preliminary screening of some Nepalese medicinal plants for antimicrobial activity. Bulletin of Department of Plant Resource 30: 87-94.

Sharma, S., A. Singh and M.P. Baral. 2002. Antimicrobial activities of essential oils of some common spices. Nepal Journal of Science and Technology 4: 95-100.

Srinivasen, D., S. Nathan, T. Suresh and P.L. Perumalsamy. 2001. Antimicrobial activity of certain Indian medicinal plants used in folklore medicine. Journal of Ethnopharmacology 74: 217-220.

Stainton, A. 1988. Flowers of the Himalayas-A Supplement. Oxford University Press: New Delhi, India.

Taylor, .R.S.L. and G.H.N. Towers. 1998. Antibacterial constituents of the Nepalese medicinal herb, Centipeda minima. Phytochemistry 47(4): 631-634.

Taylor, R.S.L., N.P. Manandhar and G.H.N. Towers. 1996a. Antimicrobial and Antiviral studies on selected medicinal plants of Nepal. In: Ethnobiology in Human Welfare, (Ed.SK. Jain), Deep Publications, India, pp. 78-82.

Taylor, R.S.L., F. Edel, N.P. Manandhar and G.H.N. Towers. 1996b. Antimicrobial activities of Southern Nepalese medicinal plants. Journal of Ethnopharmacology 50: 97-102.

Taylor, R.S.L., J.D. Hudson, N.P. Manandhar and G.H.N. Towers. 1996c. Antiviral activities of medicinal plants of Nepal. Journal of Ethnopharmacology 52:157-163.

Taylor, R.S.L., J.D. Hudson, N.P. Manandhar and G.H.N. Towers. 1996d. Antiviral activities of medicinal plants of southern Nepal. Journal of Ethnopharmacology 53: 97-104.

Taylor, R.S.L., N.P. Manandhar and G.H.N. Towers. 1995. Screening of selected medicinal plants of Nepal for antimicrobial activities. Journal of Ethnopharmacology 46: $153-159$

Taylor, R.S.L., S. Shahi and R.P. Chaudhary. 2002. Ethnobotanical research in the proposed Tinjure-MilkeJaljale Rhododendron conservation area, Eastern Nepal. In: Vegetation and Society: their interaction in the Himalayas (Eds. R.P., Chaudhary, B.P. Subedi, O.R. Vetaas, and T.H. Aase). Tribhuvan University Nepal and University of Bergen, Norway, Pp. 26-37.

Vaidya, G.S., S. Thapa, A. Shrestha and K. Shrestha. 2006. Antibacterial activity of the wild mushrooms against human pathogens. Nepal Journal of Science and Technology 7: 55-58. 